\title{
Biology and Control of Goosegrass in Sugarcane ${ }^{1}$
}

\author{
Dennis Calvin Odero, Ron Rice, and Les Baucum²
}

Goosegrass (Eleusine indica), also referred to as white crabgrass, wiregrass, bullgrass, or silver crabgrass, is an important weed species in sugarcane (SWSS 1993). Originally native to Eurasia, goosegrass is widely distributed in the United States from Massachusetts to South Dakota and Kansas, south to Florida and Texas, and also along the west coast. It is also widespread in Florida where it is commonly found in cultivated fields, turf, pastures, landscapes, orchards, roadsides, and other disturbed sites. Goosegrass is found year-round in southern Florida and is commonly associated with newly planted and stubble (ratoon) sugarcane fields.

\section{Biology and Life Cycle}

Goosegrass is an annual plant that produces a prostrate, mat-like rosette with flattened stems radiating from a central point (Figure 1). It is often described as looking like someone has stepped in the middle of the plant, flattening it out. Because of the whitish to translucent color of the leaf sheath margins, goosegrass usually appears white to silver; this is why it is known as white or silver crabgrass. It germinates when soil temperatures are above $65^{\circ} \mathrm{F}$ (Chauhan and Johnson 2008) and can grow from 4 inches up to 3 feet tall (Uva, Neil, and DiTomaso 1997). Seedling emergence is greatest for seeds on the soil surface and declines as depth of burial increases. Germination completely ceases if seeds are buried deeper than 3 inches (Chauhan and Johnson 2008).

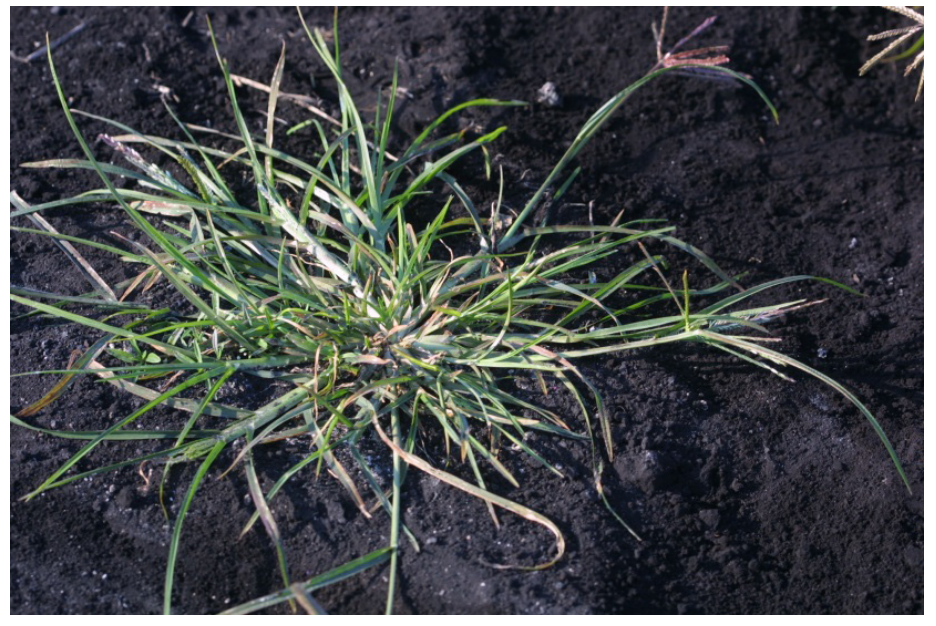

Figure 1. Goosegrass mat-like rosette with flattened stems radiating from a central point.

Credits: D. C. Odero

\section{Seedling}

The first leaf blade is usually $3-5$ times longer than it is wide, and it will open parallel to the ground. The leaves are folded in the bud and have a fringed membranous ligule. The white to translucent leaf sheath margins are broad, smooth, and flattened.

1. This document is SS-AGR-367, one of a series of the Agronomy Department, Florida Cooperative Extension Service, Institute of Food and Agricultural Sciences, University of Florida. This publication is a part of the Florida Sugarcane Handbook. For more information, contact the editor of the Sugarcane Handbook, Ronald W. Rice (rwr@ufl.edu). Original publication date January 2013. Please visit the EDIS website at http://edis.ifas.ufl.edu.

2. Dennis Calvin Odero, assistant professor, Agronomy Department, Everglades Research and Education Center, Belle Glade, FL; Ron Rice, Extension agent, Palm Beach County, Belle Glade, FL; and Les Baucum, Extension agent, Hendry County, LaBelle, FL; Florida Cooperative Extension Service, Institute of Food and Agricultural Sciences, University of Florida, Gainesville, FL 32611.

The use of trade names in this publication is solely for the purpose of providing specific information. UF/IFAS does not guarantee or warranty the products named, and references to them in this publication do not signify our approval to the exclusion of other products of suitable composition. All herbicides should be used in accordance with directions on the manufacturer's label.

The Institute of Food and Agricultural Sciences (IFAS) is an Equal Opportunity Institution authorized to provide research, educational information and other services only to individuals and institutions that function with non-discrimination with respect to race, creed, color, religion, age, disability, sex, sexual orientation, marital status, national origin, political opinions or affiliations. U.S. Department of Agriculture, Cooperative Extension Service, University of Florida, IFAS, Florida A\&M University Cooperative Extension Program, and Boards of County Commissioners Cooperating. NickT. Place, Dean 


\section{Mature Plant}

The leaf blade is flat or folded, and can grow 2-8 inches long by 1/13-1/3-inch wide. Leaf blades are mostly hairless, except occasional sparse long hairs on the upper surface near the base. The ligule is membranous and uneven. Leaf sheaths are flattened, smooth to sparsely hairy toward the ligule, and whitish at the base. The seedhead consists of 2-13 fingerlike spikes, which can be 2-6 inches long and $1 / 10-1 / 3$-inch wide at the top of stems (Figure 2). Usually one spike is below the others, which are bunched toward the tip. On the underside of each spike, there are two rows of 3-6 seeds, which are brown to black and 1/13-inch long. Goosegrass has a fibrous root system and never roots at the nodes.

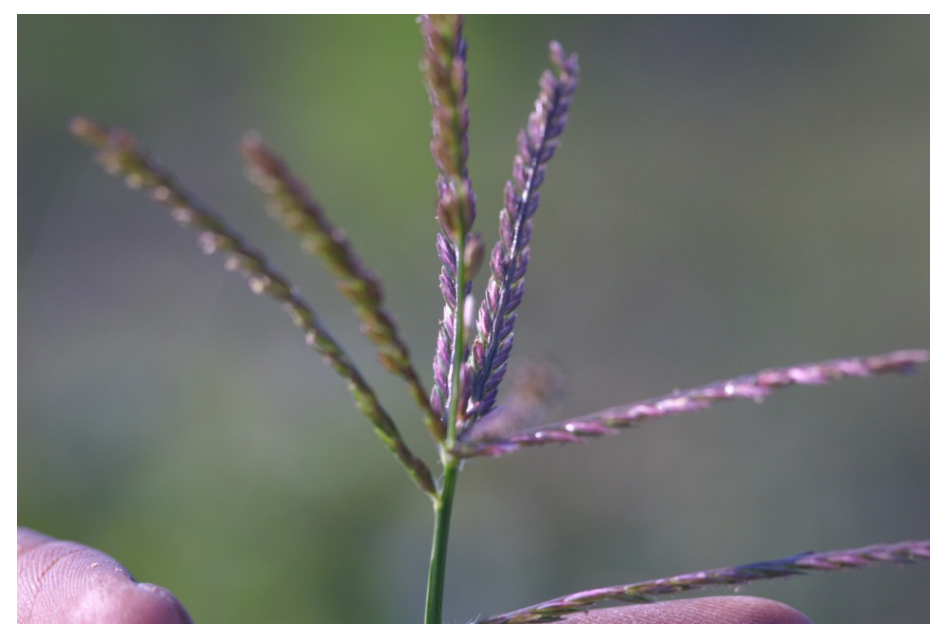

Figure 2. Goosegrass seedhead.

Credits: D. C. Odero

\section{Control}

Goosegrass is not highly competitive with sugarcane; however, severe infestations caused by a poor sugarcane stand or poor control measures can result in sugarcane yield losses (Figure 3). Goosegrass can be controlled with preemergence and postemergence herbicides (Table 1). Tillage and appropriate weed control during fallow periods can also successfully reduce goosegrass populations in sugarcane.

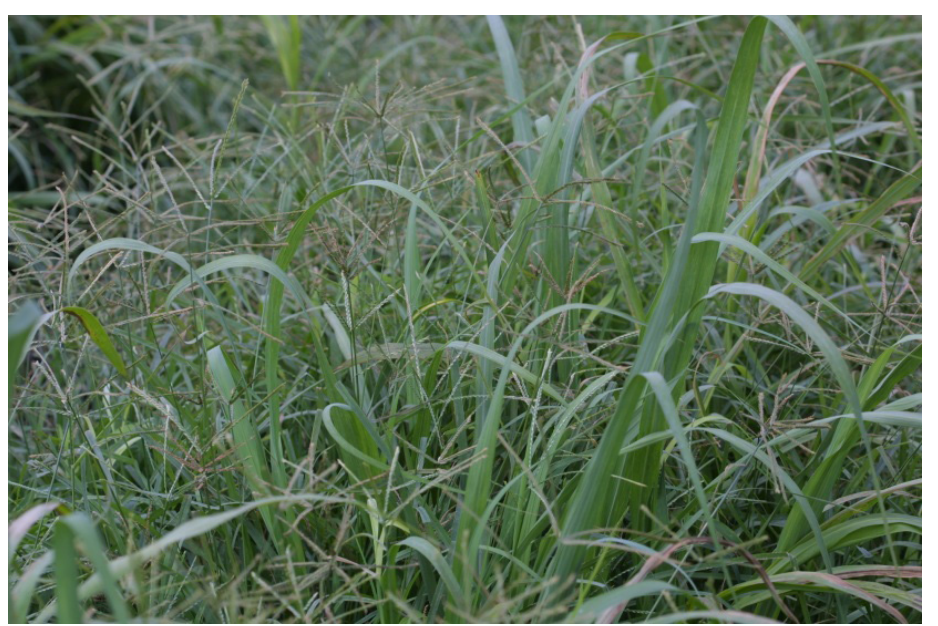

Figure 3. Severe goosegrass infestation in sugarcane. Credits: D. C. Odero

\section{References}

Chauhan, B. S., and D. E. Johnson. 2008. "Germination Ecology of Goosegrass (Eleusine indica): An Important Grass Weed of Rainfed Rice." Weed Science 56:699-706.

Southern Weed Science Society (SWSS). 1993. Weed Identification Guide. Champaign: Southern Weed Science Society.

Uva, R. H., J. C. Neil, and J. M. DiTomaso. 1997. Weeds of the Northeast. Ithaca: Cornell University Press. 
Table 1. Herbicide options for goosegrass control in sugarcane.

\begin{tabular}{|c|c|c|c|c|}
\hline Herbicide & Trade name & Rate per acre & Timing & Comments \\
\hline Metribuzin & Metribuzin & 1 1/3-2 2/3 lb & Preemergence & $\begin{array}{l}\text { Apply prior to weed emergence after planting or } \\
\text { after harvest on stubble cane. Higher rates are } \\
\text { suited for fields with a history of heavy infestation. } \\
\text { Tank-mixing with pendimethalin improves the } \\
\text { efficacy. Use on muck soils only and not on sandy } \\
\text { (mineral) soils. }\end{array}$ \\
\hline Pendimethalin & Prowl $\mathrm{H}_{2} \mathrm{O}$ & $4.2-8.4 \mathrm{pts}$ & Preemergence & $\begin{array}{l}\text { Apply prior to weed emergence after planting or } \\
\text { after harvest on stubble cane. Higher rates are } \\
\text { suited for fields with a history of heavy infestation. } \\
\text { Tank-mixing with metribuzin improves the efficacy. } \\
\text { Does not have postemergence activity. }\end{array}$ \\
\hline Metribuzin & Metribuzin & $11 / 3-22 / 3 \mathrm{lb}$ & Early postemergence & $\begin{array}{l}\text { Apply over-the-top of stubble or plant cane when } \\
\text { sugarcane is less than } 14 \text { inches tall. } \\
\text { Or apply post-directed to sugarcane that is a } \\
\text { minimum of } 14 \text { inches tall and before row closing. } \\
\text { Use on muck soils only and not sandy (mineral) } \\
\text { soils. }\end{array}$ \\
\hline Asulam & $\begin{array}{l}\text { Asulox } \\
\text { Asulam } \\
\text { (several) }\end{array}$ & $6-8 \mathrm{pts}$ & Postemergence & $\begin{array}{l}\text { Apply to plant or stubble cane when goosegrass } \\
\text { is actively growing. Lower rates should be used } \\
\text { when goosegrass is } 6-8 \text { inches tall or less. Higher } \\
\text { rates should be used if goosegrass is greater than } 8 \\
\text { inches tall. Apply with either a non-ionic surfactant } \\
\text { at } 1-2 \text { quarts per } 100 \text { gallons }(0.25-0.50 \% \text { v/v) or } \\
\text { crop oil concentrate at } 4 \text { quarts per } 100 \text { gallons ( } 1 \% \\
\text { v/v). }\end{array}$ \\
\hline Trifloxysulfuron & Envoke & 0.3 ounces & Postemergence & $\begin{array}{l}\text { Apply to seedlings less than } 6 \text { inches in height. It } \\
\text { can be broadcasted in stubble cane but only post- } \\
\text { directed in plant cane. Tank-mixing with asulam } \\
\text { at } 4 \text { pints per acre improves control of larger } \\
\text { goosegrass (more than } 12 \text { inches in height). Apply } \\
\text { with a non-ionic surfactant at } 1-2 \text { quarts per } 100 \\
\text { gallons }(0.25-0.50 \% \mathrm{v} / \mathrm{v}) \text {. }\end{array}$ \\
\hline
\end{tabular}

